\title{
PENGARUH JENIS ALAT SULING TERHADAP RENDEMEN DAN KUALITAS MINYAK KAYU PUTIH YANG DIHASILKAN
}

\author{
Oleh : \\ Eddy Sapto Hartanto *)
}

\begin{abstract}
The potency of Cajuput oils production in West Seram (SBB) very large, if support with high technology. In the momment most of apparatus still traditional distillation, that made from wood. So the yield was low. To increassing yield and quality of cajuput oils from SBB need repair of distillation technology. The experiment was conducted in SBB, on August 2007. The treatment consisted of 2 different distillation apparatus i.e apparatus made of wood and stainless steel, 6 time of distillation i.e. 1 our, 2 ours, 3 ours, 4 ours, 5 our and 6 ours. The experiment was designed in a Completely Randomized with 2 replications. Parameter observed of result distillation cajuput oils were percent of yield, percent of cineol, specify grativy, refraction, index number, optic. The results showed that distillation apparatus made stainless steel showed better performance than traditional distillation apparatus made from wood. The treatment of 3 ours (A1B3) were optimum treament with result analysis gave yeild $0,93 \%$, cineol $57,4 \%$, specify gratify 0,914 , refracy index 1,465 and optic polarization (-) 1,64.
\end{abstract}

Keywords : Melaleucaleucadendron L., cajuput oils, distillation apparatus

\section{PENDAHULUAN}

Minyak kayu putih dalam perdaganga ninternasional dikenal dengan nama cajeput essential oil atau cajeput oil. Bagi masyarakat Indonesia minyak kayu putih sudah tidak asing lagi, karena sudah menjadi kebutuhan yang cukup penting bagi setiap rumah tangga di Indonesia. Dalam kehidupan sehari-hari minyak kayu putih digunakan sebagai antiseptik, obat sakit perut, obat flu atau digunakan untuk pijatan (urut) ringan dan untuk membantu mengurangi penyakit ringan lainnya. Di bidang industri, minyak kayu putih digunakan sebagai salah satu bahan baku industri obat-obatan maupun di industri kosmetik (Lutony dan Rahmayati, 1994).

Kebutuhan minyak kayu putih di dalam negeri, dari tahun ke tahun cenderung semakin meningkat, sejalan dengan peningkatan jumlah penduduk yang membutuhkan minyak kayu putih. Saat ini kebutuhan minyak kayu putih di dalam negeri cukup besar, yaitu mencapai 1.500 ton per tahun. Dari kebutuhan sebanyak itu Indonesia baru dapat memproduksi minyak kayu putih kurang dari 500 ton, sehingga untuk kebutuhan dalam negeri, Indonesia harus mengimpor minyak kayu putih dari berbagai negara seperti China dan Vietnam (Djogo dan Subarudi, 2005).

Bagi masyarakat Kabupaten Seram Bagian Barat, keberadaan tanaman kayu putih merupakan suatu anugrah yang sangat besar bagi daerah ini. Tanaman kayu putih di daerah ini umumnya tidak ditanam atau dibudidaya secara intensif, namun tanaman ini dapat tumbuh baik dengan sendirinya tanpa ada pengelolaan oleh pemilik lahan. Potensi lahan tanaman kayu putih di Kabupaten Seram Bagian Barat mencapai 36.000 hektar (Anonymous, 2007). Namun potensi yang besar tersebut tidak diberdayakan secara maksimal. Kegiatan penyulingan minyak kayu 
putih di daerah ini, umumnya hanya sebagai kegiatan sambilan dan sistem penyulingan dilakukan menggunakan alat penyuling yang sederhana yang terbuat dari kayu. Dengan menggunakan ketel penyuling yang terbuat dari kayu, para pengrajin di daerah ini umumnya waktu yang dibutuhkan untuk menyuling minyak kayu putih mencapai lebih dari 10 jam untuk sekali suling. Sehingga usaha minyak kayu putih dirasakan kurang menguntungkan dibandingkan dengan usaha lainnya. Selama 10 jam penyulingan, pengrajin memperoleh rendemen minyak kayu putih rata-rata kurang dari $1 \%$. Hal ini sangat memberatkan, terutama untuk biaya kayu bakar dan lamanya waktu penyulingan, menjadi tidak sebanding dengan harga jual minyak kayu putih yang dihasilkan. Oleh sebab itu banyak pengrajin minyak kayu putih yang beralin ke usana lainnya yang lebih menguntungkan. Akibatnya produksi minyak kayu putih asal Kabupaten Seram Bagian Barat ini masih sangat rendah, dibandingkan dengan potensi bahan baku minyak kayu putih yang sangat besar.

Mengingat hal tersebut, maka untuk meningkatkan potensi lahan tanaman kayu putih dan peran serta masyarakat di Kabupaten Seram Bagian Barat dalam memproduksi minyak kayu putih ini, perlu diupayakan pemberdayaan melalui bimbingan dan teknologi tepat guna, agar potensi tanaman kayu putih yang ada dapat dikelola dengan baik dan dapat menghasilkan produk unggulan bagi daerah ini.

Untuk meningkatkan rendemen dan mutu minyak atsiri seperti minyak kayu putih, menurut Guenther (1950) ada beberapa faktor yang berpengaruh antara lain metode penyulingan, lamanya penyulingan, keadaan bahan dan perlakuan terhadap minyak yang dihasilkan. Mengingat bahwa sebagian besar proses penyulingan minyak kayu putih di Kabupaten Seram Bagian Barat ini masih menggunakan ketel suling yang terbuat dari kayu, maka pada penelitian ini dilakukan percobaan pengaruh jenis ketel dan lama penyulingan terhadap rendemen dan mutu minyak kayu putih yang dihasilkan.

\section{BAHAN DAN METODE}

Penelitian ini dilaksanakan di Kecamatan Seram Barat, Kabupaten Seram Bagian Barat, pada bulan Agustus 2007.

\section{Bahan}

Bahan yang digunakan dalam penelitian ini adalah daun kayu putih (Melaleuca leucadendron L. ) segar, yang diperoleh dari petani kayu putih di Desa Piru, Kabupaten Seram Bagian Barat, Propinsi Maluku, kayu bakar, air pendingin, resorcinol, khloroform, alkohol dan kapas.

\section{Alat}

Peralatan yang digunakan adalah alat suling (metode air dan uap) dengan terbuat dari bahan stainless steel berkapasitas $200 \mathrm{~kg}$ daun kayu putih segar (Gambar 1) dan alat suling tradisional (semi rebus) yang terbuat dari bahan kayu marsego (kayu kuning) dan bagian bawah ketel dilengkapi dengan wajan sebagai alat untuk mendidihkan air, berkapasitas $200 \mathrm{~kg}$ (Gambar 2). Peralatan penunjang lainnya adalah timbangan, polarimeter, refraktometer, piknometer,labu cassia, gelas ukur, tabung reaksi, pipet tetes, erlenmeyer, gelas piala dan alat laboratorium lainnya untuk analisis minyak kayu putih. 


\section{Metode}

Sebanyak $200 \mathrm{~kg}$ daun segar kayu putih masing-masing dimasukkan dalam ketel suling yang terbuat dari bahan stainless steel dan ketel suling yang terbuat dari kayu marsego. Kemudian daun kayu putih disuling dengan metode air dan uap air untuk alat suling stainless steel dan metode semi rebus untuk penyulingan menggunakan ketel dari bahan kayu marsego. Pengamatan dilakukan untuk melihat pengaruh jenis ketel suling dan lama penyulingan terhadap rendemen dan mutu minyak kayu putih yang dihasilkan. Waktu penyulingan dihitung distilat menetes pertama pada labu penampung.

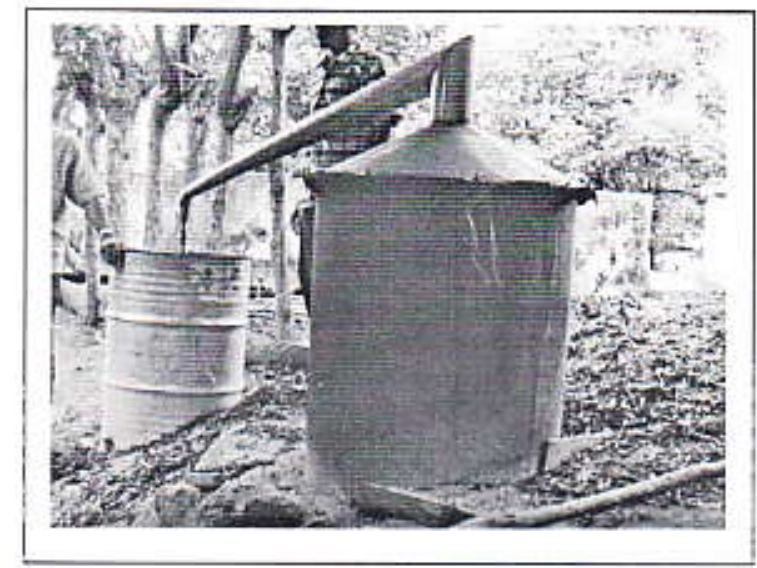

Gambar 1. Alat suling minyak kayu putih terbuat dari bahan stainless steel

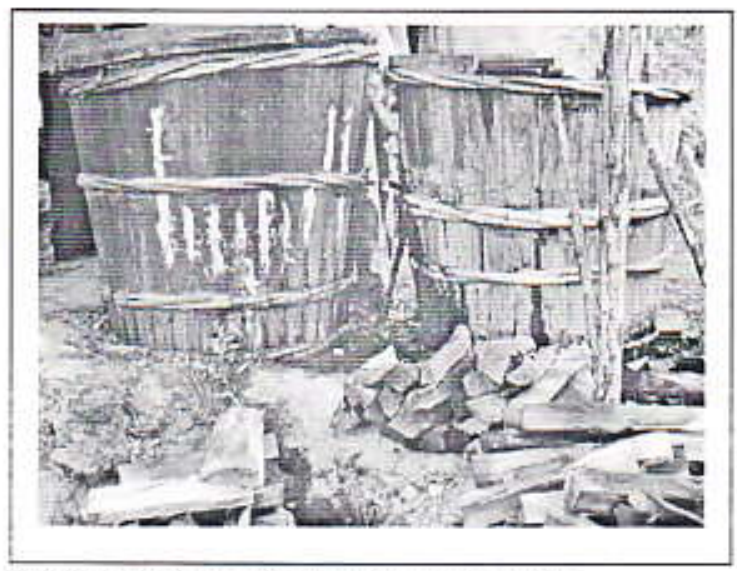

Gambar 2. Alat suling minyak kayu putih terbuat dari bahan kayu marsego (kayu kuning)

\section{Rancangan percobaan}

Rancangan percobaan yang digunakan dalam penelitian ini adalah Rancangan Acak Lengkap (RAL) 2 faktorial dan 2 kali ulangan. Faktor Aadalah jenis ketel suling yang terdiri atas 2 taraf, yaitu $\mathrm{A} 1=$ ketel suling terbuat dari bahan stainless steel dan $\mathrm{A} 2=$ ketel suling dari bahan kayu marsego. Sedangkan faktor $B$ adalah lama penyulingan yang terdiri atas 6 taraf, yaitu $B 1=1$ jam, B2 $=2$ jam B3 $=3$ jam B4 $=4$ jam, B5 $=5$ jam dan B6 $=6$ jam (Sudjana, 1985$)$.

\section{Analisis}

Setiap perlakuan penyulingan dihitung rendemennya secara akumulatif dan hasil dari setiap perlakuan dilakukan dianalisis karakteristik mutu sesuai SNI minyak kayu putih Nomor SNI 06-3954-2001 yang terdiri atas jenis analisis kadar sineol, bobot jenis (BJ), indeks bias, putaran optik, kelarutan dalam alkohol $80 \%$, uji minyak lemak dan uji minyak pelikan (Badan Standardisasi Nasional, 2001).

\section{HASILDAN PEMBAHASAN}

\section{Rendemen minyak}

Rendemen akumulasi setiap jam waktu penyulingan minyak kayu putih yang dihasilkan, terlihat bahwa semakin lama proses penyulingan akan diperoleh rendemen akumulasi semakin besar seperti terlihat pada Gambar 3. Hasil analisis sidik ragam menunjukkan bahwa penggunaan ketel suling berpengaruh nyata terhadap rendemen minyak kayu putih yang dihasilkan. Penggunaan ketel suling yang terbuat dari bahan stainless steel memberikan rendemen yang tinggi, dibandingkan dengan penggunaan ketel dari kayu. Pada grafik Gambar 3, terlihat bahwa 
rendemen akumulasi minyak kayu putih yang dihasilkan sejak mulai jam ke 1 sampai jam ke 6 semakin meningkat. Namun dilihat dari tingkat efisiensi penyulingan, proses minyak kayu putih menggunakan ketei dari bahan stainless steel selama 5 jam sudah cukup efisien dibandingkan dengan menggunakan ketel yang terbuat dari bahan kayu. Pada jam ke 5 , rendemen minyak kayu putih yang tersuling menggunakan ketel suling dari bahan stainless steel dapat mencapai 1,27 \%. Bila proses penyulingan dilanjutkan sampai jam ke 6 , hanya menghasilkan peningkatan rendeman yang relatif kecil sebesar $0,03 \%$. Sedangkan pada penyulingan menggunakan ketel yang terbuat dari kayu terlihat bahwa rendemen minyak kayu puth hanya sebesar $0,78 \%$ dan bila dilajutkan sampai 6 jam penyulingan rendemen akan bertambah $0,05 \%$ atau menjadi $0,83 \%$. Menurut Ketaren (1985) jumlah minyak yang keluar dipengaruhi oleh kecepatan minyak yang keluar dari bahan. Pendekatan pengukuran kecepatan minyak yang keluar dari bahan pada penelitian ini dilakukan dengan cara pengukur jumlan destilat yang keluar dari ketel suling yang digunakan. Pada penelitian ini distilat yang keluar dari ketel suling yang melalui proses penyulingan menggunakan ketel stainless steel lebih besar rata-rata mencapai $220 \mathrm{ml} / \mathrm{menit}$ dengan suhu destilat rata-rata $32^{\circ} \mathrm{C}$ dibandingkan dengan destilat yang keluar dari proses penyulingan menggunakan ketel dari kayu yang hanya $194 \mathrm{ml} / \mathrm{menit}$ dengan rata-rata suhu destilat $35^{\circ} \mathrm{C}$.

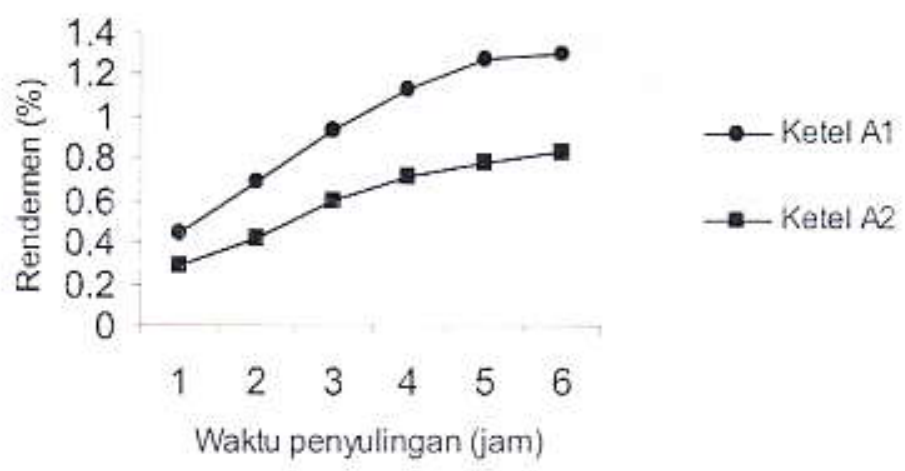

Gambar 3. Grafik rendemen akumulasi penyulingan minyak kayu putih menggunakan ketel suling terbuat dari bahan stainless steel dan kayu marsego dengan lama penyulingan yang berbeda

Penggunaan ketel suling yang terbuat dari kayu kurang efektif untuk menyuling dengan baik, karena kayu bukan merupakan penghantar panas yang baik, uap panas yang dihasilkan dari perebusan air di bagian bawah ketel tidak dialirkan secara sempurna keluar dari ketel dengan membawa minyak kayu putih. Sebagian uap yang mengandung minyak kayu putih kemungkinan ada yang meresap kedalam kayu dan sebagian lagi ada yang menguap melalui celah-celah kayu yang tidak rapat, sehingga rendemen minyak yang dihasilkan akan menjadi berkurang. Disamping itu sistem pendingin uap pada ketel tradisional ini kurang panjang dan air pendingin yang kurang serta tidak disirkulasi, sehingga proses pendinginan uap air yang membawa minyak kayu putih tidak terkondensasi dengan sempurna, keadaan ini akan berpengaruh pada tampungan distilat yang masih cukup panas dengan suhu mencapai $35^{\circ} \mathrm{C}$, pada suhu tersebut akan memudahkan minyak kayu putih yang dihasilkan sebagian menguap. Hal ini akan mengurangi rendemen minyak atsiri yang dihasilkan (Guenther, 1950).

\section{Kadar sineol}

Proses penyulingan minyak atsiri termasuk minyak kayu putih merupakan proses hidrodifusi, pada proses penyulingan ini minyak yang terkandung dalam bahan akan melarut dalam 
air atau uap panas secara osmosa. Selanjutnya akan terbawa oleh uap ke atas dan dilakukan kondensasi untuk merubah uap menjadi bentuk cair, agar mudah pemisahan antara minyak atsiri dan air. Proses ini akan berlangsung terus menerus pada suhu uap atau air mendidih, sampai minyak dalam kantong bahan baku habis. Kecepatan penguapan ini sangat tergantung mudah tidaknya komponen minyak atsiri tersebut melarut dalam air, semakin mudah melarut dalam air, maka semakin mudah minyak tersebut keluar dari sel bahan bakunya dan akan semakin mudah pula terbawa oleh uap air pada proses penyulingan (Guenther, 1949). Pada penyulingan minyak kayu putih, komponen sineol $(\mathrm{C} 10 \mathrm{H} 180)$ sebagai komponen utama merupakan fraksi ringan dan komponen ini mudah terbawa oleh uap air, sehingga sineol ini akan keluar pada tahap awal penyulingan (Ketaren, 1985).

Analisis sidik ragam menunjukkan jenis ketel suling dan lamanya proses penyulingan berpengaruh terhadap kadar sineol minyak kayun putih yang dihasilkan. Daun kayu putih yang disuling menggunakan ketel suling yang terbuat dari kayu cenderung lebih lama waktu penyulingannya, semakin lama proses penyulingan, maka kadar sineol akan semakin rendah, demikian pula sebaliknya, semakin cepat proses penyulingan maka akan semakin tinggi kadar sineolnya. Seperti terlihat pada Gambar 4.

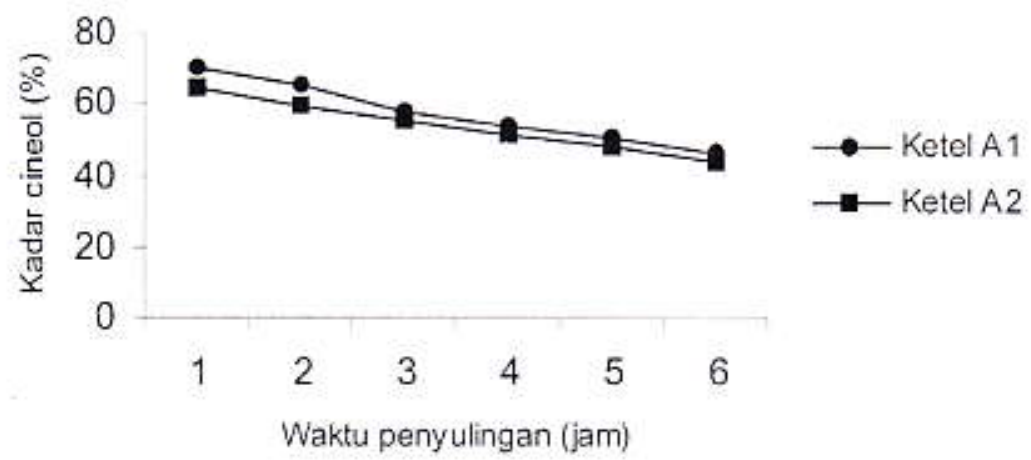

Gambar 4. Grafik kadar sineol minyak kayu putih hasil penyulingan menggunakan ketel suling terbuat dari bahan stainless steel dan kayu marsego dengan lama penyulingan yang berbeda

Pada Gambar 4 terlihat bahwa kadar sineol minyak kayu putih yang dihasilkan menggunakan alat suling dan waktu penyulingan yang berbeda menunjukkan hasil yang berbeda. kadar sineol minyak kayu putih yang disuling dengan ketel dari stainless steel, berkisar $46,5 \%$ $70,5 \%$ dan kadar sineol berkisar 43,5 - 64,5\% untuk minyak kayu putih yang disuling menggunakan ketel dari kayu. Perlakuan penyulingan jam ke 1 (A1B1) menghasilkan minyak kayu putih dengan kadar sineol tertinggi sebesar $70,5 \%$, dibandingkan dengan A2B1 hanya sebesar $64,5 \%$. Kadar sineol pada proses penyulingan sampai jam ke 3 masih memenuhi syarat SNI 063954-2001 dengan klasifikasi utama (U)A1B3 dengan kadar sineol 57,4 \% dan A2B3 55,5\% lebih tinggi dari persyaratan SNI 06-3954-2001 yang mensyaratkan kadar sineol minimum $55 \%$ untuk klasifikasi mutu U . Sedangkan lama penyulingan lebih dari 3 jam termasuk kalsifikasi Mutu Pertama berdasarkan SNI tersebut, karena kadar sineol kurang dari $55 \%$.

\section{Bobot jenis}

Nilai bobot jenis dipengaruhi oleh komponen kimia yang terkandung dalam minyak atsiri. Semakin tinggi kadar fraksi berat, maka bobot jenis akan semakin tinggi. Pada Gambar 5 terlihat bahwa semakin lama proses penyulingan, bobot jenis minyak kayu putih yang dihasilkan akan 
semakin tinggi. Hal ini disebabkan pada awal proses penyulingan yang banyak keluar adalah fraksi ringan, ini seperti terlihat banwa semakin lama penyulingan, akan dihasilkan minyak kayu putih dengan bobot jenis yang semakin tinggi.

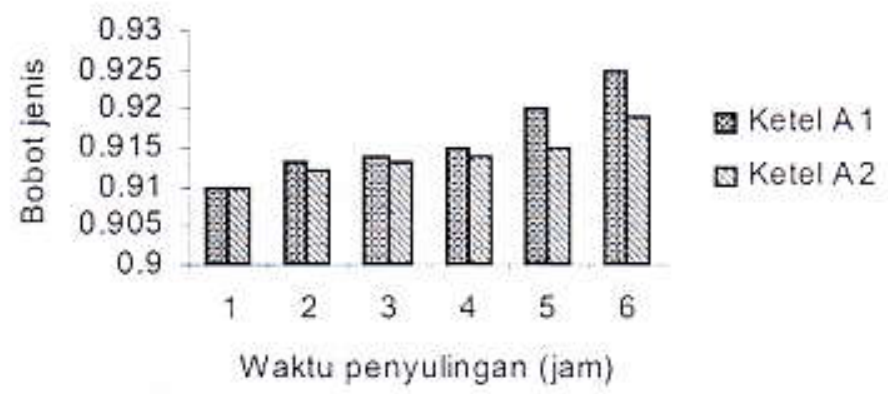

Gambar 5. Histogram bobot jenis minyak kayu putih hasil penyulingan menggunakan ketel terbuat dari bahan stainless steel dan kayu marsego dengan lama penyulingan yang berbeda

Analisis sidik ragam menunjukkan bahwa bobot jenis minyak kayu putih dipengaruhi oleh waktu proses penyulingan. Semakin lama proses penyulingan, maka bobot jenisnya akan semakin tinggi. Bobot jenis minyak kayu putih hasil penyulingan pada berbagai waktu penyulingan menunjukkan hasil yang berbeda. Minyak kayu putih yang disuling dengan ketel dari stainless steel, memiliki bobot jenis berkisar $0,91-0,925$, menggunakan ketel dari kayu bobot jenisnya berkisar $0,91-0,919$. Nilai bobot jenis minyak kayu putih yang dihasilkan menggunakan kedua jenis ketel masih memenuhi syarat SNI 06-3954-2001, yang mensyaratkan bobot jenis 0,90-0,93 Berdasarkan pengamatan ternyata minyak kayu putih yang dihasilkan menggunakan ketel yang terbuat dari stainless steel pada jam ke 6 (A1B6) memberikan nilai bobot jenis tertinggi dengan nilai 0,925 , hal ini disebabkan pada penggunaan ketel dari bahan stainless steel panas yang diperoleh lebih tinggi, dibandingkan dengan menggunakan ketel dari kayu. Sehingga fraksi berat yang terkandung dalam daun kayu putih dapat tersuling lebih cepat, dibandingkan proses penyulingan menggunakan ketel kayu dengan waktu penyulingan 6 jam (A2B6) nilai bobot jenisnya 0,919 .

\section{Indeks bias}

Indeks bias adalah ukuran bilangan yang menunjukkan perbandingan antara sinus sudut datang dengan sinus sudut bias cahaya. Minyak kayu putih merupakan minyak atsiri yang sebagian besar berupa fraksi ringan yang lebih mudah menguap. Hasil analisis indeks bias minyak kayu putih yang dihasilkan pada proses penyulingan menggunakan ketel suling yang berbeda dapat dilihat pada Gambar 6 .

Pada Gambar 6, terlihat bahwa, semakin lama proses penyulingan maka indeks bias akan semakin tinggi. Analisis sidik ragam menunjukkan bahwa lama penyulingan berpengaruh terhadap nilai indeks bias minyak kayu putih yang dihasilkan. Pada lama penyulingan 1 jam perlakuan A1B1 dengan indeks bias 1,461 dan A2B1 sebesar 1,459. Indeks bias akan naik terus sejalan dengan lamanya penyulingan sampa pada waktu penyulingan selama 6 jam nilai indeks bias A1B6 sebesar 1,486 dan A2B6 sebesar 1,472. Kenaikkan indeks bias ini disebabkan oleh sebagian fraksi ringan komponen minyak kayu putih telah tersuling lebih dahulu, dibandingkan dengan komponen fraksi beratnya. Proses penyulingan yang lebih lama akan dapat menyuling fraksi berat yang dapat meningkatkan kerapatan molekul komponen minyak kayu putih. Akibatnya sinar yang menembus minyak kayu putih lebih mudah menembus dan diteruskan dibandingkan dengan hasil minyak kayu 
putih yang tersuling dengan waktu yang lebih lama. Dengan demikian semakin lama penyulingan akan semakin tinggi nilai indeks bias minyak kayu putih yang dihasilkan dan sebaliknya semakin singkat waktu penyulingan akan semakin rendah indeks biasnya.

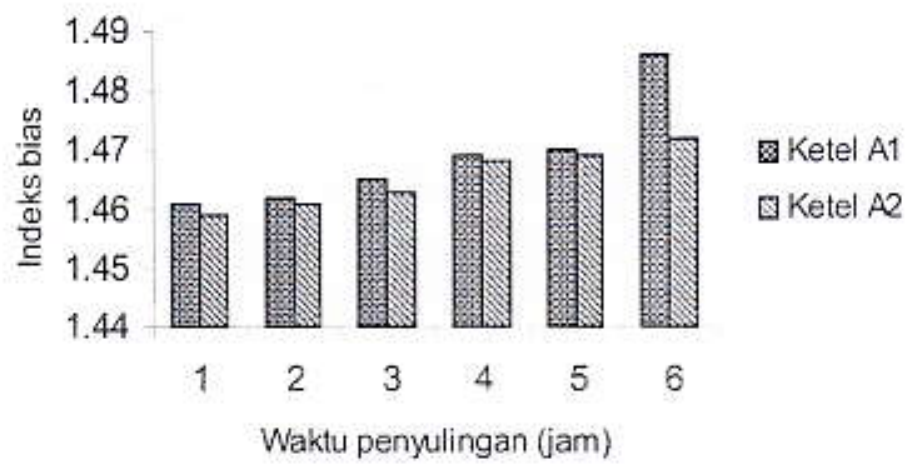

Gambar 6 . Histogram indeks bias minyak kayu puth hasil penyulingan menggunakan ketel terbuat dari bahan stainless steel dan kayu marsego dengan lama penyulingan yang berbeda

Pada proses penyulingan selama 5 jam nilai indeks bias minyak kayu putih yang dihasilkan pada perlakuan menggunakan ketel stainless steel berkisar 1,461 - 1,470 dan menggunakan ketel dari kayu 1,459-1,469 masih memenuhi syarat SNI 06-3954-2001, yang mensyaratkan indeks bias 1,46-1,47. Sedangkan pada penyulingan jam ke 6 menggunakan kedua jenis ketel nilai indeks biasnya tidak memenuhi persyaratan SN! 06-3954-2001, karena hasil periakuan A1B6 dengan indeks bias 1,486 dan A2B6 sebesar 1,472 lebih tinggi dari yang disyaratkan SNI Minyak Kayu Putih.

\section{Putaran optik}

Putaran optik merupakan besaran yang menyatakan gabungan nilai putaran optik senyawa penyusun minyak atsiri. Pada Gambar 7 terlihat bahwa semakin lama waktu penyulingan, maka nilai putaran optik minyak kayu putih yang dihasilkan semakin memberikan nilai negatif.

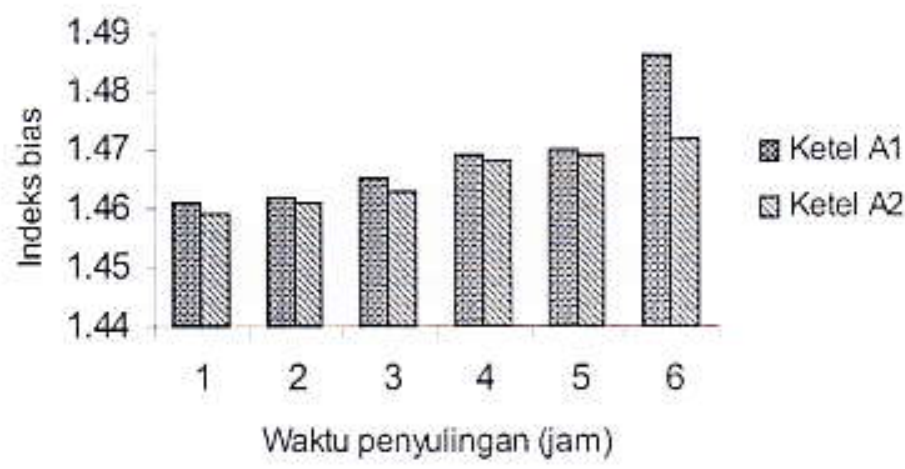

Gambar 7. Histogram putaran optik minyak kayu putih hasil penyulingan menggunakan ketel terbuat dari bahan stainless steel dan kayu marsego pada lama penyulingan yang berbeda

Analisis sidik ragam menunjukkan bahwa lama penyulingan mempengaruhi putaran optik minyak kayu putih yang dihasilkan. Pada lama penyulingan 1 jam perlakuan A1B1 dengan putaran optik (-) 1,36 ${ }^{\circ}$ dan dan A2B1 (-) 1,32 . Putaran optik akan semakin memutar ke kiri sejalan dengan bertambahnya waktu penyulingan. Pada waktu penyulingan selama 6 jam putaran optik 
A1B6 sebesar (-) $5,48^{\circ}$ dan A2B6 (-) 4,58 . Pada proses penyulingan minyak kayu putih akan ikut tersuling juga senyawa $\alpha$ - terpineol yang bersifat optis inaktif dalam bentuk bebas atau terikat, yang merupakan senyawa kedua terpenting dalam minyak kayu putih setelah sineol. Adanya senyawa $\alpha$ - terpineol inilah yang menyebabkan minyak kayu putih bersifat leavorotasi (optis inaktif) dalam minyak kayu putih. Putaran optik hasil penyulingan minyak kayu putih menggunakan kedua ketel suling sampai waktu penyulingan selama 5 jam, masih memenuhi persyaratan SNI 06-3954-2001 yang mensyaratkan putaran optik $(-4)-0^{\circ}$. Sampai jam ke 5 hasil penyulingan minyak kayu putih perlakuan A1B5 dengan putaran optik $\left(-3,95^{\circ}\right)$ dan A2B5 $\left(-2,84^{\circ}\right)$. Sedangkan pada penyulingan selama 6 jam putaran optiknya melebihi persyaratan $\mathrm{SNI}$ tersebut, karena A1B6 dengan putaran optik(-) $5,48^{\circ}$ danA2B6(-) $4,58^{\circ}$.

\section{Kelarutan dalam alkohol}

Kelarutan daiam alkohol $80 \%$ merupakan salah satu persyaratan SNI 01-06-3954-2001. Hasil analisis sidik ragam, menunjukkan bahwa minyak kayu putih yang dihasilkan menggunakan 2 jenis ketel suling dan lama penyulingan tidak mempengaruhi parameter kelarutan dalam alkohol 80 $\%$. Minyak kayu putih yang dihasilkan memenuhi syarat SNI 06-3954-2001, karena minyak kayu putih tersebut dapat larut dalam alkohol,mulai $1: 1,1: 2,1: 3$ dan seterusnya. Menurut Heath (1978), minyak atsiri yang memiliki senyawa terpen dengan konsentrasi yang tinggi, sukar larut dalam alkohol, sedangkan minyak atsiri yang mengandung senyawa terpen-o mudah larut dalam alkohol. Dalam penyulingan minyak kayu putih, sebagian besar senyawa yang tersuling adalah sineol yang termasuk golongan ester sebagai turunan terpen alkohol, yang mempunyai titik didih lebin rendah, sehingga pada proses penyulingan senyawa ini akan keluar lebih dulu. Oleh sebab itu minyak kayu putih yang dihasilkan lebih mudah larut dalam alkohol $80 \%$.

\section{Analisis usaha penyulingan minyak kayu putih}

Minyak kayu putih memiliki pasar yang sangat luas, untuk memenuhi permintaan dalam negeri saja, sampai saat ini masih dirasa kekurangan pasokan. Total kebutuhan minyak kayu putih sebanyak 1500 ton, baru bisa dipasok oleh produsen dalam negeri kurang dari 500 ton. Sisa kebutuhan dalam negeri sampai saat ini masih dipasok dari China dan Vietnam. Dari informasi yang terakhir dikumpulkan, permintaan minyak kayu putih selalu meningkat dan sering terjadi kelebihan permintaan yang tidak dapat dipenuhi oleh kapasitas produksi industri kecil minyak kayu putih yang terbatas. Permintaan dalam jumlah besar untuk waktu yang singkat biasanya diusahakan secara berkelompok. Usaha kayu putih, merupakan usaha yang cukup menguntungkan baik dari segi usaha budidaya tanaman kayu putih maupun dari segi penyulingan minyak atsiri.

Untuk industri kecil minyak kayu putih dengan pemilikan 1 alat suling yang terbuat dari bahan stainless steel dengan kapasitas $200 \mathrm{~kg}$ sekali suling dan lama penyulingan selama 5 jam serta menggunakan bahan bakar kayu, maka gambaran perhitungan tekno-ekonomi penyulingan kayu putih adalah sebagai berikut :

Spesifikasi : Kapasitas alat suling $200 \mathrm{~kg}$ dua kali suling per hari 
No.

Uraian

Tahun I

Tahun II

\section{PENGELUARAN}

1. Pembelian alat suling (Stainless Steel) berkapasitas $200 \mathrm{~kg}$

Rp 15.000 .000

2. Bahan baku ( 2 kali suling per hari) $400 \mathrm{~kg} \times \operatorname{Rp} 300 \times 250$ hari

$\operatorname{Rp} 30.000 .000$

$\operatorname{Rp} 30.000 .000$

3. Bahan bakar (kayu)

Rp $15.000 \times 250$ hari

$\operatorname{Rp} 3.750 .000$

Rp 3.750 .000

4. Kemasan

Rp $\quad 500.000$

Rp $\quad 500.000$

5. Tenaga kerja Rp 20.000/HOK

Penyulingan 2 orang $\times 250$ hari

$=500 \mathrm{HOK}$

Total Pengeluaran

Rp 10.000 .000

Rp 10.000 .000

Rp 59.250 .000

Rp 44.250 .000

॥ PENDAPATAN

1. Produksi minyak $4 \mathrm{~kg} / \mathrm{hari}$ rendemen minyak rata-rata $1 \%$

$1,000 \mathrm{~kg}$

$1,000 \mathrm{~kg}$

2.Penjualan@ Rp 110.000,-/kg

Rp 110.000 .000

Rp 110.000 .000

3. Keuntungan

Rp 50.750 .000

Rp 65.750 .000

4. Keuntungan kumulatif

Rp 50.750 .000

$\operatorname{Rp} 116.500 .000$

III PERTIMBANGAN USAHA

1. BEP (Break Event Point)
a. BEP Harga
Rp $59.250 .000: 1.000 \mathrm{~kg}$
Rp $59.250 / \mathrm{kg}$
b. BEP Produksi
Rp $59.250 .000: \operatorname{Rp} 110.000$
$584 \mathrm{~kg}$ (dalam 7 bulan)
2. B/C Ratio
Rp $110.000 .000: \operatorname{Rp} 59.250 .000$
$\mathrm{B} / \mathrm{C}$

Keterangan : Harga perkiraan tersebut berdasarkan data dan informasi di wilayah Kabupaten Seram bagian Barat, pada saat dilakukan penelitian ini.

Setiap penambahan biaya $R p 1$,- akan memperoleh penerimaan $R p 1,85$, atau usaha memberikan keuntungan investasi sebesar $85 \%$ per tahun.

\section{KESIMPULAN}

Dari hasil penelitian proses penyulingan minyak kayu putih ini dan perhitungan teknoekonomi untuk industri kecil dengan kapasitas produksi $200 \mathrm{~kg}$ sekali suling dapat disimpulkan bahwa:

1. Penggunaan ketel suling dari bahan stainless steel menghasilkan rendemen lebih tinggi dibandingkan menggunakan ketel yang terbuat dari kayu.

2. Rendemen optimum proses penyulingan minyak kayu putih diperoleh pada jam ke 5 , dengan 
total rendemen A1B5 1,27 \% dan A2B5 $0,78 \%$. Penambahan waktu penyulingan tidak memberikan rendemen tambahan yang nyata,

3. Lama penyulingan akan berpengaruh terhadap kadar sineol, bobot jenis, indeks bias, putaran optik. Semakin lama penyulingan kadar sineol kadar sineol akan semakin rendah, bobot jenis semakin naik, indeks bias semakin naik dan putaran optik akan semakin bersifat optis inaktif.

4. Kombinasi perlakuan terbaik terbaik ditinjau dari mutu minyak kayu putih yang dihasilkan adalah perlakuan penyulingan menggunakan ketel suling yang terbuat dari bahan stainless steel dan lama penyulingan 3 jam (A1B3) menghasilkan rendemen $0,93 \%$, kadar sineol $57,4 \%$, bobot jenis 0,914 , indeks bias 1,465 dan putaran optik $(-) 1,64$, telah memenuhi persyaratan SNI 06-3954-2001 dengan Klasifikasi Mutu Utama (U).

5. Usaha industri kecil minyak kayu putih dapat memberikan keuntungan sebesar $85 \%$ per tahun.

\section{DAFTAR PUSTAKA}

Anonymous (2007). Selayang Pandang Kabupaten Seram Bagian Barat. Bupati Seram Bagian Barat.

[BSN] Badan Standardisasi Nasional. (2001) Standar Nasional Indonesia (SNI) 06.3954 - 2001 Minyak Kayu Putih, Badan Standardisasi Nasional, Jakarta.

Djogo, T. dan Subarudi (2005) Minyak Kayu Putih: Produksi dan Kebutuhan Dalam Negeri, http://www.beritabumi.or.id.

Guenther, E. (1949) Essential Oils. Vol I. Van Nostrand Reinhold Co., New York.

Guenther, E. (1950) Essential Oils. Vol IV. Van Nostrand Reinhold Co., New York.

Heath, H.B. (1978). Flavor Technology Profiles, Product, Applications. The AVI Publishing Co., Inc., Westport.

Ketaren, S. (1985). Pengantar Teknologi Minyak Atsiri, Balai Pustaka, Jakarta.

Lutony, T.L. dan Y. Rahmayati (1994). Produksi dan Perdagangan Minyak Atsiri. Cetakan ke IV, Penebar Swadaya, Jakarta.

Sudjana (1985). Disain dan Eksperimen, Tarsito, Bandung. 